A-P [okagon]

1895 


\section{HARVARD UNIVERSITY.}

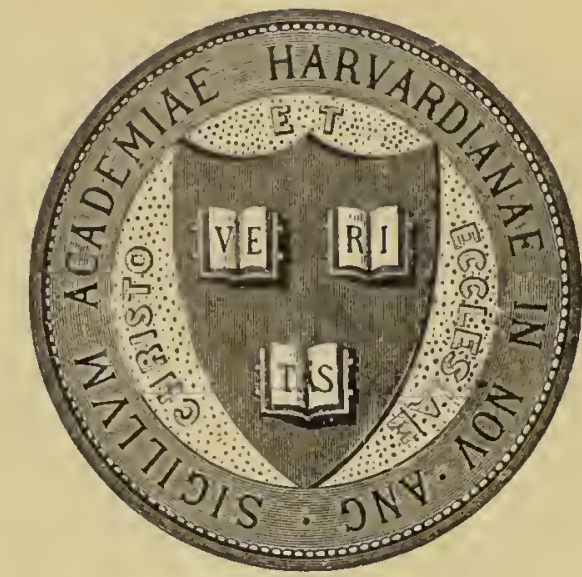

\section{LIBRARY}

OF THE

MUSEUM OF COMPARATIVE ZOÖLOGY $5 \cong .100$

BEQUEST OF

WILLIAM BREWSTER

May 12, 1920 


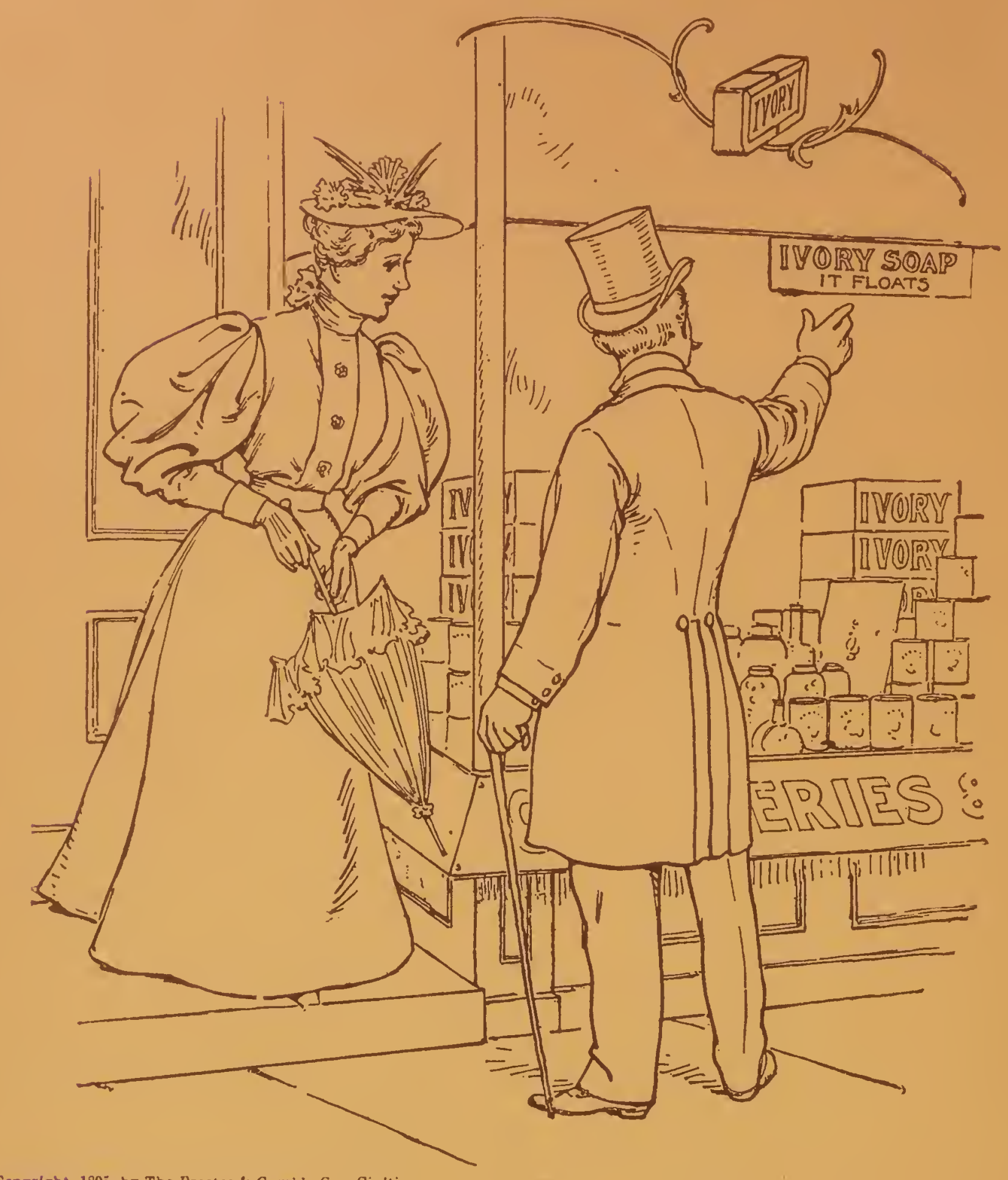

Copyright, 1895, by The Procter \& Gamble Co., Cin'ti.

\section{If Ivory were not the best} soap it would not be found at more grocery stores than any other.

The vegetable oils of which lvory Soap is made, and its purity, fit it for many special uses for which other soaps are unsafe and unsatisfactory. Ivory Soap is sold by more dealers and used in more households than any other.

M. 11 . 
ends of the ropes to the one ascending, and then grasp him under the arms to help him up the ship ladder. Above on deck, at the end of the ladder, stand two more sailors as ladder men, who are ready to take the visiting officer's coat or render any other service. If a commander comes on board a ship he is received by six ladder men, an admiral by eight. When the ruler of a country arrives he is received by only four ladder men, not sailors however, but officers in full uniform. The higher officers coming on board are further honored with the roll of the drum, whistles, and the presenting of arms. For a commander there is simply the presenting of muskets, for the beginning of which the boatswain's mate of the guard gives two shrill whistles and two more at its conclusion. In honor of admirals, besides presenting arms and the whistles, there is the rolling of drums, which for a rear admiral is repeated twice, for a vice-admiral three times, and for a commanding admiral four times. The first roll must occur simul. taneously with the first whistle of the boatswain's mate, the second with the second whistle.

Marine etiquette requires, moreover, that officers come on the ship over the starboard side. Only persons of higher rank are allowed to pass over the stapboard side especially of ships lying in harbor; sailors, merchants and other visitors have to go to the ladder on the larboard side. The starboard side is especially/honored on board, and the aft deck is a sacred room. Marine etiquette requires that the officers belonging to the ship, even the commander, on entering the aft deck pay homage to this room by laying the hand on the cap. Under no circumstances may/the crew venture into this room, except on duty, unless by command. As soon as they have reached the upper deck they must show it honor by their bearing and parade step. To the land-lubber this/obeisance to a certain room may appear somewhat ridiculous, but there is a grain of common sense in this old custom. Whoever enters the aft deck knows that he is under the ban of the strongest ship discipline. the crew is ordered to the aft deck, a certain conscious start goes through its men, for they know that something weighty is to be dealt with, and it is unheard of the annals of seafaring nations for the grew of a warship to mutiny while on the aft deck.

Even the boats of warships/which pass by a warship in harbor must proceed according to a certain etiquette. The international directions say that if by day, boats pass a warship on which there is a higher officer, they must pay him the honor of having the crew rest on their oars for a moment, that is to stop rowing, and with oars raised out of the water to sit perfectly still while the ffficer or boat's commander salutes and finally dips the boat flag. 'The same hongt is shown by the guard on the warship to a higher officer passing by as if he came aboard. If a rowboat meets an admipal, it makes a halt, the crew rise froun the benches and at the command, "Oars up!" they hold the oars perpenAicularly, in much the same manner as the infantry present their muskets. Steamboats show honor by stopping, bringing to and dipping their flags; sailboats by letting down the sail half or wholly as well as lowering the flag.

At evening the sailors at all the posts on the forecastle of the ship, that is at the prow and the manropes, call out to a passing ship, "Boat ahoy!" The answers that are given are in every case determined by regulations. If the boat is not coming aboard it calls, "Pass!" and there is a certain answer to tell whether an officer is on board; if there is no officer in the boat and it is to come aboard; if the ruler of a country or a prince is in the boat; if it is an admiral or a commodore approaching; and if the commander of the ship in question is in the boat, the steersman calls the name of the ship, such as "Leipsic," "Bismarck," and so forth.

This bare sketch of the outlines of international marine etiquette will enable the reader to see that its ceremonials require much attention, much work, much wasting If of powder, and consequently much expense. 


\title{
TEIF WILD PIGEON OF NORTH AMERICA.
}

\author{
BY CHIEF POKAGON.*
}

$\mathrm{T}$ Ame migratory or wild pigeon of North o-me-me-wog. Why the European race did not accept that name was, no doubt, because the bird so much resembled the domesticated pigeon; they naturally called it a wild pigeon, as they called us wild men.

This remarkable bird differs from the dove or domesticated pigeon, which was imported into this country, in the grace of its long neck, its slender bill and legs, and its narrow wings. Its length is I $6 \mathrm{x} / 2$ inches. Its tail is eight inches long, having twelve feathers, white on the under side. The two center feathers are longest, while five arranged on either side diminish gradually each one half inch in length, giving to the tail when spread an almost conical appearance. Its back and upper part of the wings and head are a darkish blue, with a silken velvety appearance. Its neck is resplendent in

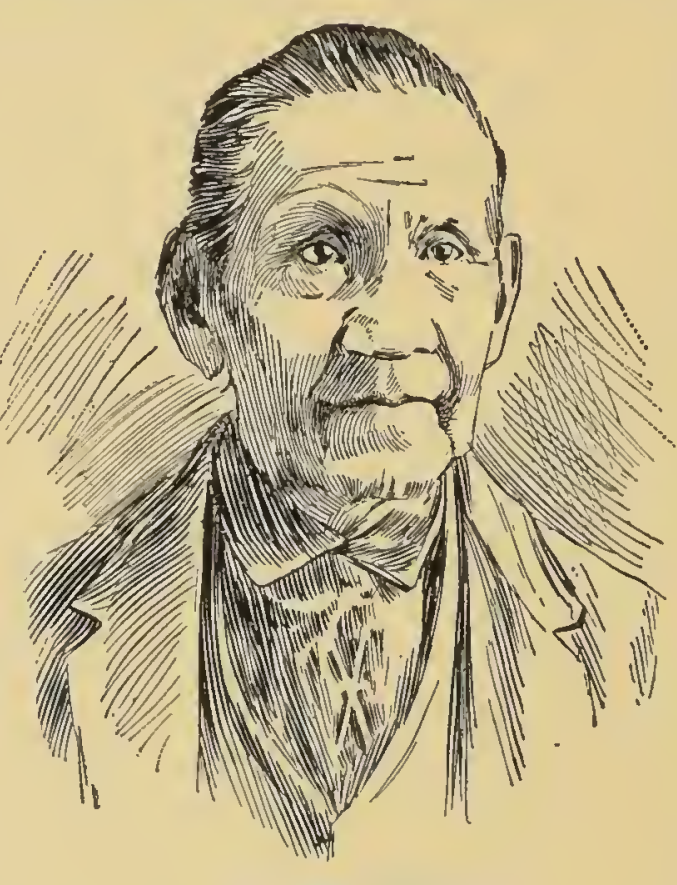

CHIEF SIMON POKAGON white, intermixed with bluish black. The female is one inch shorter than the male, and her color less vivid.

It was proverbial with our fathers that if the Great Spirit in His wisdom could have created a more elegant bird in plumage, form, and movement, He never did.

When a young man I have stood for hours admiring the movements of these birds. I have seen them fly in unbroken lines from the horizon, one line succeeding another from morning until night, moving their unbroken columns like an army of trained soldiers pushing to the front, while detached bodies of these birds appeared in different parts of the heavens, pressing forward in haste like raw recruits preparing for battle. At other times I have seen them move in one unbroken column for hours across the sky, like some great river, ever varying in hue; and as the mighty stream, sweeping on at sixty miles an hour, gold and green with royal purple intermixed. reached some deep valley, it would pour its Its breast is reddish brown, fading toward living mass headlong down hundreds of the belly into white. Its tail is tipped with feet, sounding as though a whirlwind was

\footnotetext{
*Simon Pokagon, of Michigan, is a full-blooded Indian, the last Pottawattamie chief of the Pokagon band. He is author of the "Red Man's Greeting," and has been called by the press the "Redskin poet, bard, and Longfellow of his race." His father, chief before him, sold the site of Chicago and the surrounding country to the United States in $18_{33}$ for three cents an acre. He was the first red man to visit President Lincoln after his inauguration. In a letter written home at the time he said: "I have met Lincoln, the great chief; he is very tall, has a sad face, but he is a good man, I saw it in his eyes and felt it in his hand-shaking. He will help us get payment for Chicago land." Soon after $\$ 39,000$ was paid. In 1874 he visited President Grant. He said of him: "I expected he would put on military importance, but he treated me kindly, gave me a cigar, and we smoked the pipe of peace together." In 1893 he procured judgment against the United States for over roo, ovo still due on the sale of Chicago land by his father. He was honored on Chicago Day at the World's Fair by first ringing the new Bell of Liberty and speaking in behalf of his race to the greatest crowd ever assembled on earth. After his specch "Glory Hallelujah" was sung before the bell for the first time on the Fair grounds.
} abroad in the land. I have stood by the grandest waterfall of America and regarded the descending torrents in wonder and astonishment, yet never have my astonishment, wonder, and admiration been so stirred as when I have witnessed these birds drop from their course like meteors from heaven.

While feeding, they always have guards on duty, to give alarm of danger. It is made by the watch bird as it takes its flight, beating its wings together in quick succession, sounding like the rolling beat of a suare drum. Quick as thought each bird repeats the alarm with a thundering sound, 
as the flock struggles to rise, leading a stranger to think a young cyclone is then being born.

I have visited many of the roosting places of these birds, where the ground under the great forest trees for thousands of acres was covered with branches torn from the parent trees, some from eight to ten inches in diameter. At such a time so much confusion of sound is caused by the breaking of limbs and the continual fluttering and chattering that a gun fired a few feet distant cannot be heard, while to converse so as to be understood is almost impossible.

About the middle of May, I850, while in the fur trade, I was camping on the head waters of the Manistee River in Michigan. One morning on leaving my wigwam I was startled by hearing a gurgling, rumbling sound, as though an army of horses laden with sleigh bells was advancing through the deep forests toward me. As I listened more intently I concluded that instead of the tramping of horses it was distant thunder; and yet the morning was clear, calm, and beautiful. Nearer and nearer came the strange commingling sounds of sleighbells, mixed with the rumbling of an approaching storm. While I gazed in wonder and astonishment, I beheld moving toward me in an unbroken front millions of pigeons, the first I had seen that season. They passed like a cloud through the branches of the high trees, through the underbrush and over the ground, apparently overturning every leaf. Statuelike I stood, half concealed by cedar boughs. They fluttered all about me, lighting on my head and shoulders; gently I caught two in my hands and carefully concealed them under my blanket.

I now began to realize they were mating, preparatory to nesting. It was an event which I had long hoped to witness; so I sat down and carefully watched their movements, amid the greatest tumult. I tried to understand their strange language, and why they all chatted in concert. In the course of the day the great on-moving mass passed by me, but the trees were still filled with them sitting in pairs in convenient crotches of the limbs, now and then gently fluttering their half spread wings and uttering to their mates those strange bell-like wooing notes which I had mistaken for the ringing of bells in the distance.

On the third day after, this chattering ceased and all were busy carrying sticks with which they were building nests in the same crotches of the limbs they had occupied in pairs the day before. On the morning of the fourth day their nests were finished and eggs laid. The hen birds occupied the nests in the morning, while the male birds went out into the surrounding country to feed, returning about ten o'clock, taking the nests, while the hens went out to feed, returning about three o'clock. Again changing nests, the male birds went out the second time to feed, returning at sundown. The same routine was pursued each day until the young ones were hatched and nearly half grown, at which time all the parent birds left the brooding grounds about daylight. On the morning of the eleventh day after the eggs were laid I found the nesting grounds strewn with egg shells, convincing me that the young were hatched. In thirteen days more the parent birds left their young to shift for themselves, flying to the east about sixty miles, when they again nested. The female lays but one egg during the same nesting.

Both sexes secrete in their crops milk or curd with which they feed their young, until they are nearly ready to fly, when they stuff them with mast and such other raw material as they themselves eat, until their crops exceed their bodies in size, giving to them an appearance of two birds with one head. Within two days after the stuffing they become a mass of fat, "a squab." At this period the parent bird drives them from the nests to take care of themselves, while they fly off within a day or two, sometimes hundreds of miles, and again nest.

It has been well established that these birds look after and take care of all orphan squabs whose parents have been killed or are missing. These birds are long lived, having been known to live twenty-five years caged. 
When food is abundant they nest each month in the year.

Their principal food is the mast of the forest, except when curd is being secreted in their crops, at which time they denude the country of snails and worms for miles around the nesting grounds. Because they nest in such immense bodies, they are frequently compelled to fly from fifty to one hundred miles for food.

During my early life I learned that these birds in spring and fall were seen in their migrations from the Atlantic to the Mississippi River. This knowledge, together with my personal observation of their countless numbers, led me to believe they were almost as inexhaustible as the great ocean itself. Of course I had witnessed the passing away of the deer, buffalo, and elk, but I looked upon them as local in their habits, while these birds spanned the continent, frequently nesting beyond the reach of cruel man.

Between 1840 and 1880 I visited in the states of Ohio, Indiana, and Michigan many brooding places that were from twenty to thirty miles long and from three to four miles wide, every tree in its limits being spotted with nests. Yet notwithstanding their countless numbers, great endurance, and long life, they have almost entirely disappeared from our forests. We strain our eyes in spring and autumn in vain to catch a glimpse of these pilgrims. White men tell us they have moved in a body to the Rocky Mountain region, where they are as plenty as they were here, but when we ask red men about them who are familiar with the mountain country, they shake their heads in disbelief.

A pigeon nesting was always a great source of revenue to our people. Whole tribes would wigwam in the brooding places. They seldoin killed the old birds, but made great preparation to secure their young, out of which the squaws made squab butter and smoked and dried them by thousands for future use. Yet under our manner of securing them they continued to increase.

White men commenced netting them for market about the year i 840 . These men were known as professional pigeoners, from the fact that they banded themselves together, so as to keep in telegraphic communication with these great moving bodies. In this they became so expert as to be almost continually on the borders of their brooding places. As they were always prepared with trained stool pigeons and flyers which they carried with them, they were enabled to call down the passing flocks and secure as many by net as they were able to pack in ice and ship to market. In the year 1848 there were shipped from Catteraugus County, N. Y., eighty tons of these birds; and from that time to I 878 the wholesale slaughter continued to increase, and in that year there were shipped from Michigan not less than three hundred tons of these birds. During the thirty years of their greatest slaughter there must have been shipped to our great cities 5,700 tons of these birds; allowing each pigeon to weigh one half pound would show twenty-three millions of these birds. Think of it! And all these were caught during their brooding season, which must have decreased their numbers as many more. Nor is this all. During the same time hunters from all parts of the country gathered at these brooding places and slaughtered them without mercy.

In the above estimate are not reckoned the thousands of dozens that were shipped alive to sporting clubs for trap shooting as well as those consumed by the local trade throughout the pigeon districts of the United States.

These experts finally learned that the birds while nesting were frantic after salty mud and water, so they frequently made near the nesting places, what was known by the craft as mud beds, which were salted, to which the birds would flock by the million. In April, I876, I was invited to see a net over one of these death pits. It was near Petoskey, Michigan. I think I am correct in saying the birds piled one upon another at least two feet deep when the net was sprung, and it seemed to me that most of them escaped the trap, but on killing and counting, there were found to be over one hundred dozen, all nesting birds.

When squabs of a nesting became fit for 
market, these experts prepared with climbers would get into some convenient place in a tree top loaded with nests, and with a long pole punch out the young, which would fall with a thud like lead on the ground.

In May, r880, I visited the last known nesting place east of the Great Lakes. It was on Platt River in Benzie County, Michigan. There were on these grounds many large white birch trees filled with nests. These trees have manifold bark, which when old hangs in shreds like rags or flowing moss, along their trunks and limbs. This bark will burn like paper soaked in oil. Here for the first time I saw with shame and pity a new mode for robbing these birds' nests, which I look upon as being devilish. These outlaws to all moral sense would touch a lighted match to the bark of the trees at the base, when with a flash more like an explosion the blast would reach every limb of the tree and while the affrighted young birds would leap simultaneously to the ground, the parent birds, with plumage scorched, would rise high in air annid flame and smoke. I noticed that many of these squabs were so fat and clumsy they would burst open on striking the ground. Several thousand were obtained during the day by that cruel process.

That night I staid with an old man on the highlands just north of the nesting. In the course of the evening I explained to him the cruelty that was being shown to the young birds in the nesting. $\mathrm{He}$ listened to me in utter astonishment and said, "My God, is that possible!" Remaining silent a few moments with bowed head, he looked up and said, "See here, old Indian, you go out with me in the morning and I will show you a way to catch pigeons that will please any red man and the birds too."

Early the next morning I followed him a few rods from his hut, where he showed me an open pole pen, about two feet high, which he called his bait bed. Into this he scattered a bucket of wheat. We then sat in ambush so as to see through between the poles into the pen. Soon they began to pour into the pen and gorge themselves. While I was watching and admiring them, all at once to my surprise they began fluttering and falling on their sicles and backs and kicking and quivering like a lot of cats with paper tied over their feet. He jumped into the pen saying, "Come on, you redskin."

I was right on hand by his side. A few birds flew out of the pen apparently crippled, but we caught and caged about one hundred fine birds. After my excitement was over I sat down on one of the cages, and thought in my heart, "Certainly Pokagon is dreaming, or this long-haired white man is a witch." I finally said, "Look here, old fellow, tell me how you did that." He gazed at me, holding his long white beard in one hand, and said with one eye half shut and a sly wink with the other, "That wheat was soaked in whisky." His answer fell like lead upon my heart. We had talked temperance together the night before, and the old man wept as I told him how my people had fallen before the intoxicating cup of the white man, like leaves before the blast of autumn. In silence I left the place, saying in my heart, "Surely the time is now fulfilled, when false prophets shall show signs and wonders to seduce, if it were possible, even the elect."

I have read recently in some of our game sporting journals, "A warwhoop has been sounded against some of our western Indians for killing game in the mountain region." Now if these red men are guilty of a moral wrong which subjects them to punishment, I would most prayerfully ask in the name of Him who suffers not a sparrow to fall unnoticed, what must be the nature of the crime and degree of punishment awaiting our white neighbors who have so wantonly butchered and driven from our forests these wild pigeons, the most beautiful flowers of the animal creation of North America.

In closing this article I wish to say a few words relative to the knowledge of things about them that these birds seem to possess.

In the spring of 1866 there were scattered throughout northern Indiana and southern Michigan vast numbers of these birds. On April ro in the morning they commenced moving in small flocks in diverging lines 
toward the northwest part of Van Buren County, Michigan. For two days they continued to pour into that vicinity from all directions, commencing at once to build their nests. I talked with an old trapper who lived on the brooding grounds, and he assured me that the first pigeons he had seen that season were on the day they commenced nesting and that he had lived there fifteen years and never known them to nest there before.

From the above instance and hundreds of others I might mention, it is well established in my mind beyond a reasonable doubt, that these birds, as well as many other animals, have communicated to them by some means unknown to us, a knowledge of distant places, and of one another when separated, and that they act on such knowledge with just as much certainty as if it were conveyed to them by ear or eye. Hence we conclude it is possible that the Great Spirit in His wisdom has provided them a means to receive electric communications from distant places and with one another.

$$
\begin{aligned}
& \text { The Chantarquan } \\
& x \times 11 \text {, no.2, hon. 1895. }
\end{aligned}
$$

IN THE GLORIOUS AUTUMN DAYS.

BY CHARLOTTE W. THURSTON.

$\mathrm{K} Y$, and rocks, and river,

On the hills the purple haze,

Flaming fire-flakes falling

Where the maples are ablaze!

$\mathrm{O}$ the joy of living

In the glorious autumn days!

I see the elm-trees bend and sway

I see the white clouds flecked with gray;

I see the chasing shadows play

Across the hillside far away

I see the poplar's silver sheen,

Beyond, the willow's cloudy green,

The sunny waters' flash between,

The rocky pasture, brown and bare,

The sunlight hele, the shadow there;

With brow upturned to wind and storm

One mighty pine-tree's giant form;

The larghes tossing branches wide,

The gak-tree in his leafy pride,

Thy graceful birch-a trembling bride-

Her slim white form against his side.

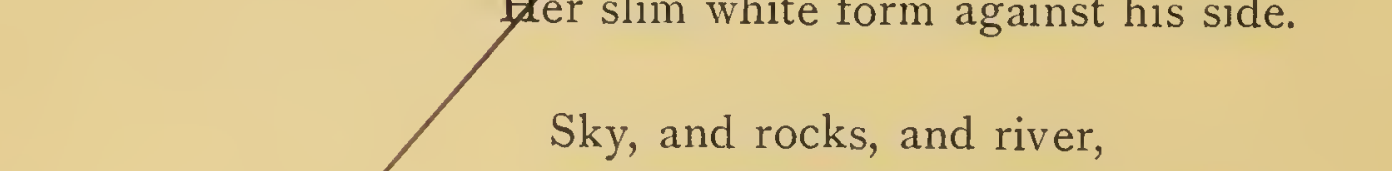

On the hills the purple haze,

Flaming fire-flakes falling

Where the maples are ablaze!

$\mathrm{O}$ the joy of living

In the glorious autumn days! 


\section{Horsford's Acid Phosphate}

Overworked men and women, the nervous, weak, and debilitated will find in the Acid Phosphate a most agreeable, grateful and harmless stimulant, giving renewed strength and vigor to the entire system.

Dr: Edwin F. Vose, lortland, Me., say: : "I have t.sed it in my own case when suffering from nervo 's exhatustion, with gratifying results. I ha e prescribed it for many of the various for of nervous debility, and it has ner

$\begin{array}{cc}\text { Ne. }-1 . & \text { Jhlet free on application to } \\ \text { Rumfora } & \text { ical Works, Providence, R. I. } \\ \text { Beware of } & \text { ilbstitutes and Imitations. }\end{array}$ For sa!e by all Druggists.

\section{Exhaustion}

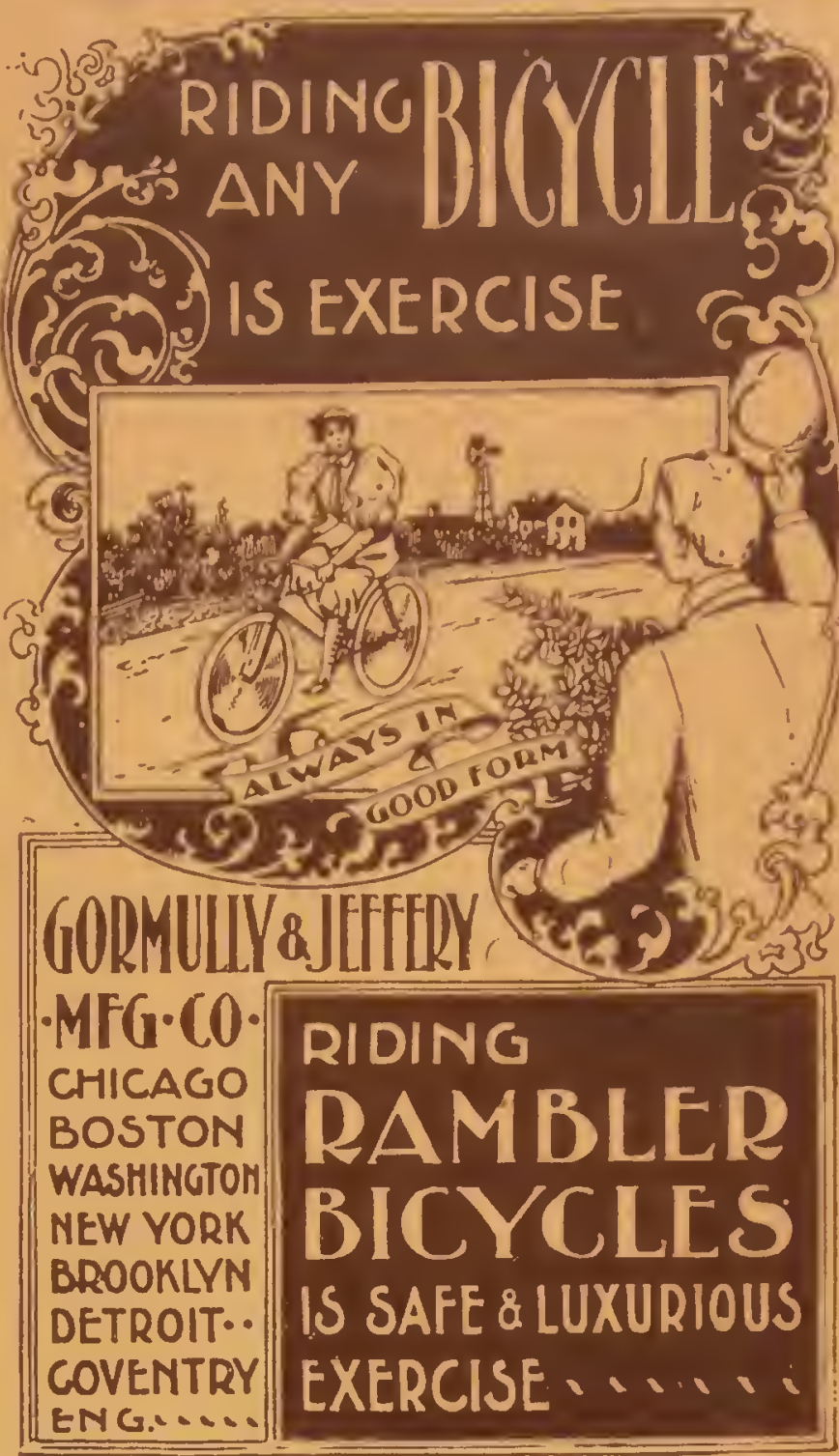

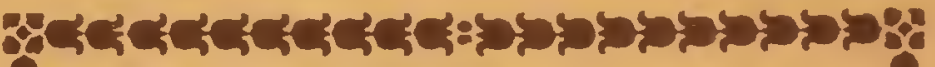

I'r. II. K. Writ.ke says: : The difference between Poi l's Extract and so-called Witch I Tazel is the differ"..nce between a cent and a dollar."

Dr. II. F . MERRIIL says: "It is far superior to any I have usfed in strength and purity."

I)r. R J. II.ARRISon says: "I have never foum any ext;act equal to Pond's."

1)r. Powelu says: "Hereafter I shall use no other than Fond's Fixtract."

And numerous others of similer purport.

To proprictery article in the m.r.ket is so much imposed upon as Fond's Fixtract; lut the poor quality of Witch Hazel heing manufactured, and the poor results obtained by usinis it, are fast educating the public to

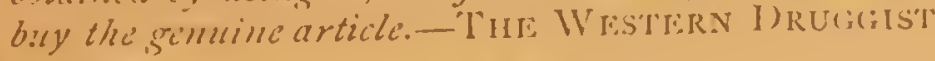

And that's why.

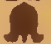

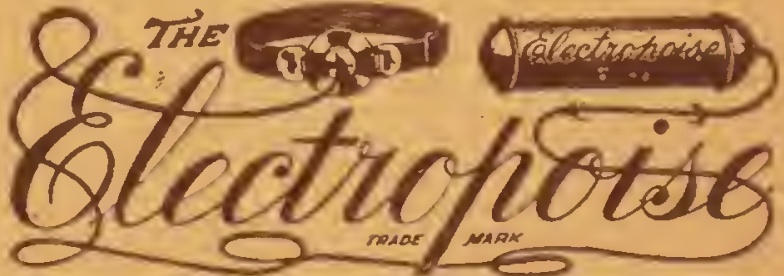

An Oxygen

Home Remedy

Without Medicine.

in

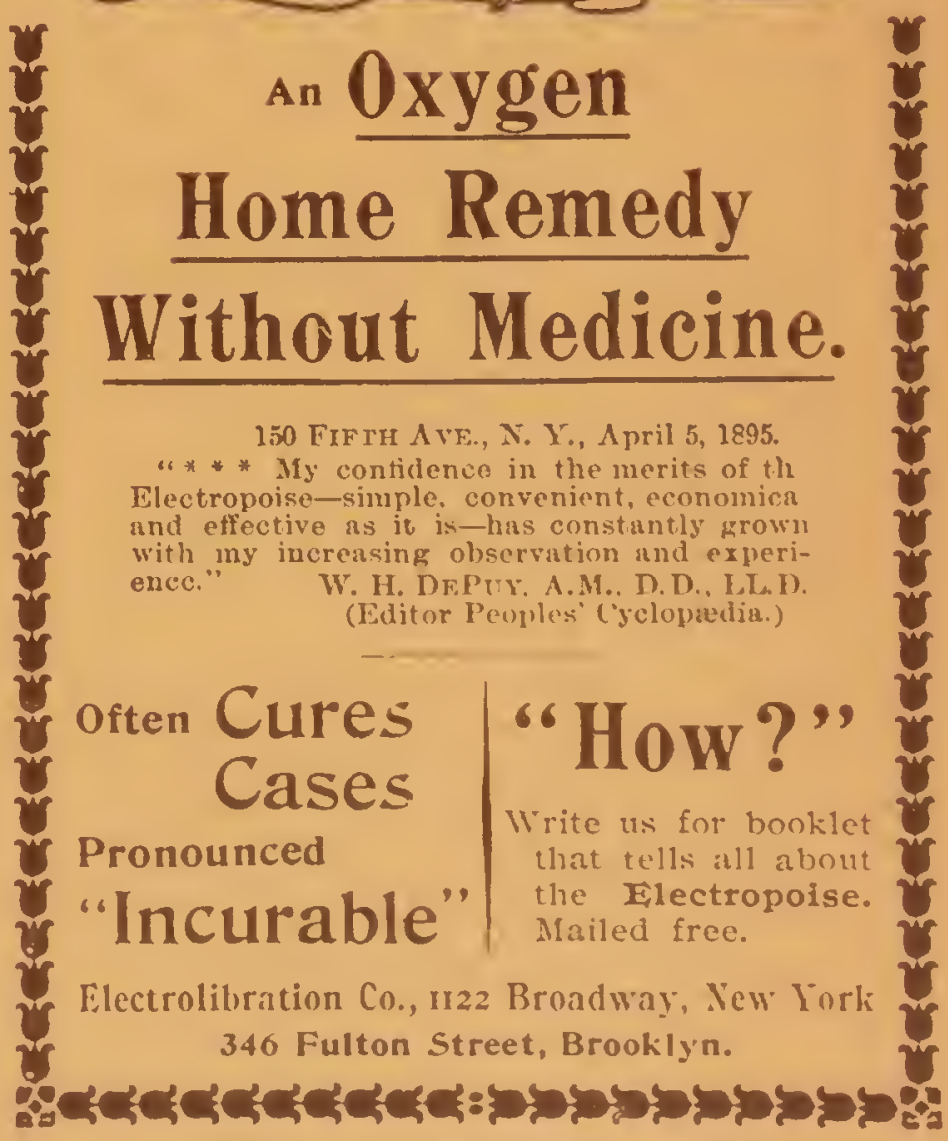




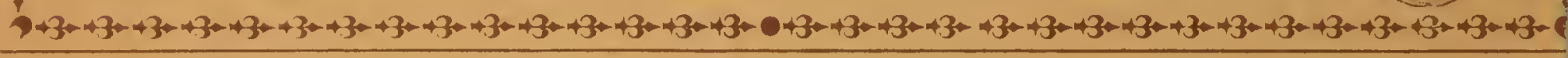
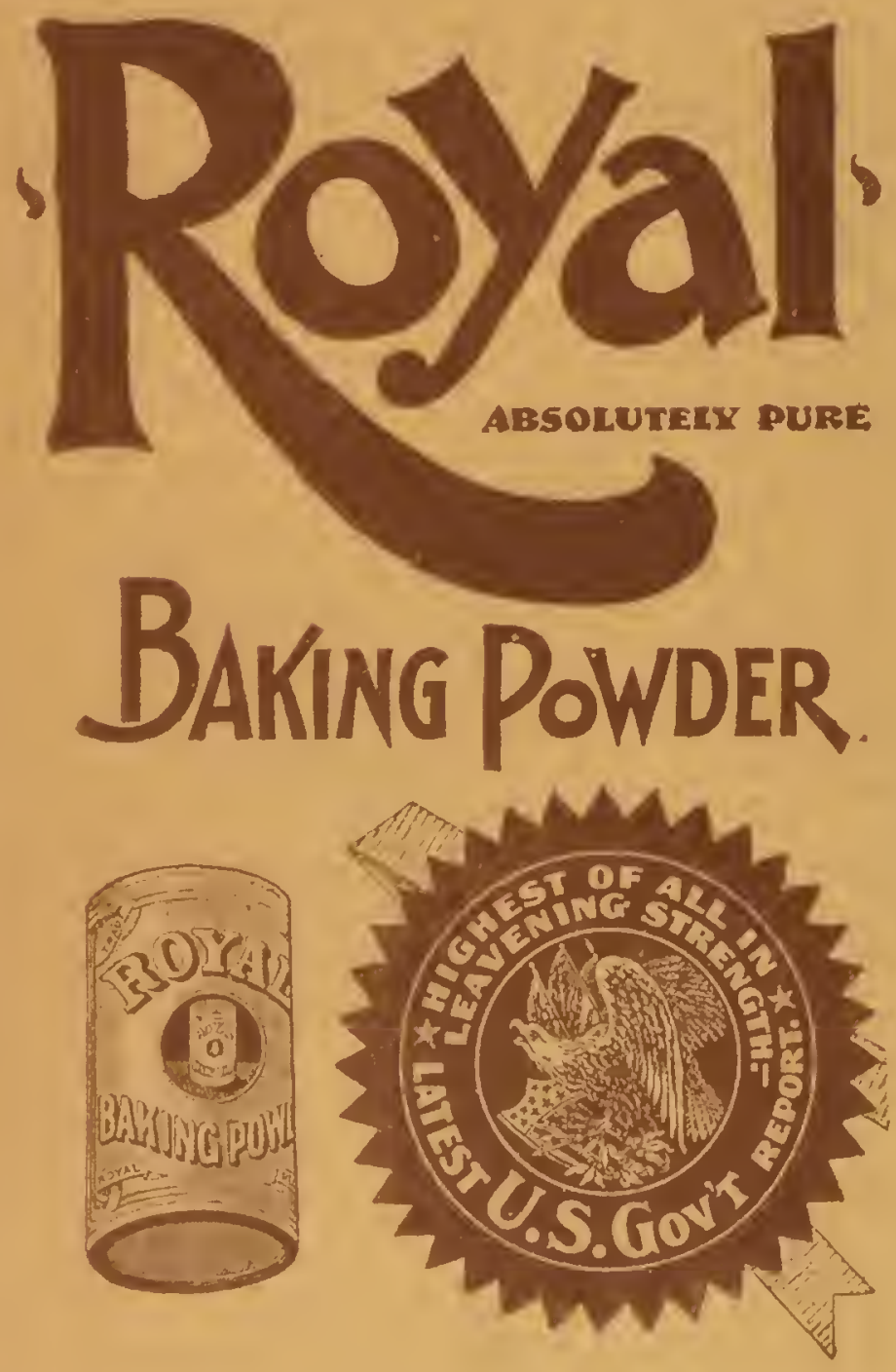

The Greatest Medical Discovery of the Age.

KENNEDY'S MEDICAL DISCOVERY,

DONALD KENMEDY, OF ROXBURY, MASS.,

Has discovered in one of our common pasture weeds a remedy that cures every kind of Humor, from the worst Scrofula down to a common Pimple.

He has tried it in over eleven hundred cases, and never failed except in two cases (both thunder humor). He has now in his possession over two hundred certificates of its value, all within twenty miles of Boston. Send postal card for book.

A benefit is always experienced from the first bottle, and a perfect cure is warranted when the right quantity is taken.

When the lungs are affected it causes shooting pains, like needles passing through them ; the same with the Liver or Bowels. This is caused by the ducts being stopped, and always disappears in a week after taking it. Read the label.

If the stomach is foul or bilious it will cause squeamish feelings at first.

No change of diet ever necessary. Eat the best you can get, and enough of it. Dose, one tablespoonful in water at bedtimc. Sold by all Dragglsts. 
